\title{
Trichoderma atroviride ISOLATED FROM MANGROVES OF THE EAST COAST OF PENINSULAR MALAYSIA EXHIBITED HIGH TOLERANCE AGAINST HEAVY METAL CADMIUM
}

\author{
SITI ATHIRAH MOHAMAD JAMALI ${ }^{1}$, NOOR AFIZA BADALUDDIN ${ }^{2}$, SYARUL NATAQAIN BAHARUM $^{3}$, \\ JAMILAH MOHD SALIM ${ }^{4}$, AZIZ AHMAD 5 and MARIAM TAIB ${ }^{*}$
${ }^{1}$ Institute of Marine Biotechnology, Universiti Malaysia Terengganu, 21030 Kuala Nerus, Terengganu ${ }^{2}$ School of Agriculture Science and Biotechnology, Faculty of Bioresources and Food Industry, Universiti Sultan Zainal Abidin, Kampus Besut, 22200, Besut, Terengganu, Malaysia ${ }^{3}$ Institute of Systems Biology, Universiti Kebangsaan Malaysia, 43600 Bandar Baru Bangi, Selangor ${ }^{4}$ Institute of Tropical Biodiversity and Sustainable Development, Universiti Malaysia Terengganu, 21030 Kuala Nerus, Terengganu
${ }^{5}$ Faculty of Science and Marine Environment, Universiti Malaysia Terengganu, 21030 Kuala Nerus, Terengganu
*E-mail:mariamt@umt.edu.my

Accepted 27 November 2020, Published online 25 December 2020

\begin{abstract}
The toxicity of the heavy metal cadmium to organisms is known, with differing tolerance in different organisms. The ability of fungi to survive in sites polluted with heavy metals has led to its mechanism of heavy metal tolerance being widely investigated. However, little work has addressed cadmium tolerance in fungi isolated from mangroves, the heavy metal basin. Therefore, this study was carried out to isolate fungi and investigate their tolerance towards cadmium. Samples used were obtained from the mangroves in the east coast of Peninsular Malaysia. Aquatic fungal isolates were selected for cadmiumtolerance screening, in the range of 0 to $0.5 \mathrm{mM}$. The identification of the most tolerant fungus was confirmed using the molecular approach and used further to study its tolerance in higher concentrations of cadmium. A total of 25 fungi was isolated and seven isolates were classified as aquatic fungi. Trichoderma sp. was shown to be the most tolerant towards cadmium. The sequencing result of the amplified fungal gene confirmed its identity as Trichoderma atroviride. Further tolerance test showed that the fungus survived in $3.0 \mathrm{mM}$, the highest concentration tested, although at a slower growth rate and with affected sporulation. These results can be the baseline data for further investigations on the mechanism of cadmium detoxification in T. atroviride, thus enhancing its potential as a heavy metal bioremediator.
\end{abstract}

Key words: Mangrove fungus, east coast Peninsular Malaysia Trichoderma atroviride, tolerance, cadmium

\section{INTRODUCTION}

Heavy metals concentrations in the environment due to natural processes and human activities have increased. These concentrations cannot be degraded or destroyed and thus will remain in the environment and could affect it and the living organisms in it (Järup et al., 2003; Morais et al., 2012; Jaishankar et al., 2014). At high concentrations, heavy metals can react to form toxic compounds in cells and tend to persist indefinitely in the food chain. Among the heavy metals,

\footnotetext{
* To whom correspondence should be addressed.
}

cadmium is a relatively rare earth element that is almost uniformly distributed in the earth crust and is probably the most biotoxic (Sadiq et al., 1992). Cadmium occurs naturally everywhere in air, water, soils and foodstuffs and therefore is widely used in various industrial products and processes. The production of cadmium and cadmium products, their use and final disposal represent only a very small fraction of the total sources of all human cadmium exposure, which is less than 2\% (ICdA et al., 2009). However, cadmium has a biological half-life of about 20 years in the human body. At low-level long-term exposure, concentrations of cadmium in urine reflect in kidneys, where approximately onethird of the body burden is found (Friberg \& Vahter, 
1983). Hence, it is very important to decontaminate cadmium and other heavy metals.

Heavy metals from the contaminated locations are removed through chemical and physical approaches which are generally effective in the treatment of high concentration of metals but less effective in the removal of metals in low concentration (10-100 ppm) (Simonescu \& Ferdes, 2012; Chen et al., 2017). A biological approach using certain organisms which can survive in high concentrations of metals and have the potential to accumulate different metals has been explored. As for cadmium, its tolerance in different organisms, especially in plant species, was reported many years ago (Coughtrey \& Martin, 1977). Simon (1977) investigated the cadmium tolerance in higher plants, Festuca ovina and Agrostis tenuis, which was isolated from mining sites and an aerially contaminated site. Plants have developed defence systems that ensure efficient cadmium detoxification by complexation and vacuolar sequestration (Heiss et al., 2003). Several studies of cadmium tolerance in microorganisms such as Schizosaccharomyces pombe (Murasugi et al., 1981) and S. cerevisiae (Kneer et al., 1992) have been conducted. In bacteria, a wide range of efflux pumps has been shown to mediate metal detoxification (Silver \& Phung, 1996). It has been suggested that different organisms have different mechanisms of cadmium detoxification depending on their biological reactions.

Among the microbes, bioremediation by fungi has become the preferred method because fungal biomass has a high percentage of cell wall materials which mainly consist of polysaccharides, proteins, and lipids, with many functional groups that can be used in metal bonding (Simonescu \& Ferdes, 2012). They also exhibit versatile biosorbent characteristics as they can grow under extreme conditions of $\mathrm{pH}$, temperature and nutrient, apart from high metal concentration (Anand et al., 2006). However, little work has addressed the resistance towards cadmium in fungi isolated from mangroves, an ecosystem which has been considered as a heavy metal basin. This study was carried out to isolate fungi from mangroves of the east coast of Peninsular Malaysia, screen their tolerance towards cadmium and investigate its growth pattern in the presence of cadmium.

\section{MATERIALS AND METHODS}

\section{Sampling sites}

Sampling for mangrove fragments was conducted in the mangrove areas at Tok Bali, Kelantan and Universiti Malaysia Terengganu (UMT), Terengganu. The root, stem, and leaf samples from intertidal and aerial parts of Avicennia alba, Rhizophora apiculata, and Sonneratia caseolaris were collected and washed with seawater to remove adhering mud before fungal isolation in the laboratory.

\section{Isolation of fungi associated with mangroves}

The isolation of fungi was carried out using Direct Plating Technique (Jones \& Hyde, 1988) that is commonly applied to isolate endophytic fungi. The roots, stems and leaves were cut into small fragments of approximately $3 \mathrm{~cm}$ in length. Then, the samples were washed with $95 \%(\mathrm{v} / \mathrm{v})$ ethanol for $1 \mathrm{~min}$ followed by $5 \%(\mathrm{v} / \mathrm{v})$ hypochlorite solution for $30 \mathrm{sec}$ and rinsed with distilled water for $1 \mathrm{~min}$ to remove any possible contamination from the surface of the samples. The sterile samples were then placed onto Potato Dextrose Agar (PDA) and Sea Water Agar (SWA) incorporated with $0.5 \mathrm{~g} / \mathrm{L}$ antibiotics. The samples were incubated in the dark, at room temperature for at least 5 days to induce growth and sporulation. After five to seven days, the colonies that had grown on the agar plates were isolated to obtain a pure culture.

\section{Morphological identification of fungal isolates}

The identification of fungi was conducted using the simple Slide Culture Technique (Riddel et al., 1950). Slide cultures of the fungal isolates were then observed using the light microscope for their morphology which includes the color of hyphae, appearance of spores, and texture of cultures. The morphology observed was then referred to the identification keys based on several references by Kohlmeyer and Kohlmeyer (1979), Sarma and Hyde (1999), Jones and Alias (1997), Barnett and Hunter (1998), Deacon (1997), Gupta (2004), Dighton et al. (2005), Ellis et al. (1992) and Dix and Webster (1995).

\section{Screening for cadmium-tolerant aquatic fungi}

The screening for aquatic fungi which are tolerant to cadmium toxicity was carried out by growing the marine fungi on SWA and freshwater fungi on PDA containing different concentrations of $\mathrm{CdCl}_{2}$ in the range of 0 to $0.5 \mathrm{mM}$ (Min et al., 1997). Seven species of fungi previously identified as aquatic fungi were placed on the agar plates and were incubated in the dark at $27^{\circ} \mathrm{C}$ for seven days. The growth of fungi on treatment medium was observed as weak growth (mycelia covering only a small part of media; +), moderate growth (mycelia covering three-quarter of media; ++), good growth (mycelia covering the whole media; +++ ) or no growth (-) (Luo et al., 2005). The fungus that tolerated the highest concentration of cadmium was selected for further experiment. 


\section{Molecular identification of the most tolerant fungus}

Molecular identification was performed to further confirm the identification of the selected fungus. Firstly, the fungus was grown in $100 \mathrm{~mL}$ $\mathrm{PDB}$ and incubated for seven days at $27^{\circ} \mathrm{C}$ with shaking at $120 \mathrm{rpm}$ in a dark condition. Following a modified method of Jaeckel et al. (2005), the culture was filtered through Whatmann No. 54 filter paper using vacuum filtration to collect the mycelia, washed twice with distilled water, and tamped dry between filter papers. The dried mycelia were stored at $-80^{\circ} \mathrm{C}$ for one day.

The genomic DNA was extracted using the Wizard Genomic DNA Purification protocol (Promega) according to the manufacturer's instructions. The quality of the DNA was evaluated using UV Vis Spectrophotometer (Shimadzu, Japan) at $260 \mathrm{~nm}$ and $280 \mathrm{~nm}$ and followed by $1.2 \%(\mathrm{v} / \mathrm{v})$ agarose gel electrophoresis. The targeted DNA strands were amplified in a total Polymerase Chain Reaction (PCR) mixture of $25 \mu \mathrm{L}$ using an Eppendorf Mastercycler Gradient. The reaction mixture was prepared by mixing 1.5 to $3.0 \mu \mathrm{M}$ $\mathrm{MgCl}_{2}, 1 \times$ PCR buffer ( $1 \mathrm{mM}$ Tris- $\mathrm{HCl}$ and $5 \mathrm{mM}$ $\mathrm{KCl}), \sim 100 \mathrm{ng}$ of template DNA, $200 \mu \mathrm{M}$ dNTPs, $1 \mathrm{U}$ Taq DNA polymerase, and 100 moles of each reversed and forward primers. The $28 \mathrm{~S}$ ribosomal RNA gene identification was carried out using primer pairs: LROR 5'-ACCCGCTGAACTTAAGC3' and LR7 5'-TACTACCACCAACATCT-3', which are normally used in genotypic identification.

The PCR was performed following the standard procedure: initial denaturation step at $95^{\circ} \mathrm{C}$ for $2 \mathrm{~min}$ followed by 35 cycles for each denaturation $\left(94^{\circ} \mathrm{C}\right.$ for $1 \mathrm{~min})$, primer annealing $\left(50^{\circ} \mathrm{C}\right.$ for $\left.1 \mathrm{~min}\right)$ and primer extension $\left(72^{\circ} \mathrm{C}\right.$ for $\left.1 \mathrm{~min}\right)$. The final extension step was at $72^{\circ} \mathrm{C}$ for $8 \mathrm{~min}$ and holding at $4{ }^{\circ} \mathrm{C}$. The PCR product was analysed on electrophoresis using $1.2 \%(\mathrm{v} / \mathrm{v})$ agarose gel and visualized by staining with ethidium bromide. The amplicon was purified after ascertaining their integrity before it was sent for sequencing. The sequences were then aligned using the database retrieved from NCBI integrated database, GenBank, EMBL, and DDBJ using BLAST at http://www.ncbi.nlm.nih.gov/blast.

\section{Higher cadmium-tolerance study}

The selected fungus was cultured in $25 \mathrm{~mL}$ PDA supplemented with $0.25,0.5,0.75,1.0,1.25,1.75$, 2.0, 2.25, 2.5, 2.75 and $3.0 \mathrm{mM} \mathrm{CdCl}$ and incubated at $30^{\circ} \mathrm{C}$ in the dark for 14 days. The control culture was grown without $\mathrm{CdCl}_{2}$. The diameter of the fungal mycelia was measured at intervals of two days to determine its growth as described by Luo et al. (2005).

\section{RESULTS AND DISCUSSION}

\section{Isolation and identification of mangrove fungi}

Based on the three key features which are the color of hyphae, the appearance of spores, and texture of cultures, 11 species of fungi were isolated from the mangroves of Universiti Malaysia Terengganu and 19 were isolated from the mangroves of Tok Bali, Kelantan (Table 1). The species isolated from the mangrove area in UMT were Absidia corymbifera, Acremonium sp., Chrysosporium sp., Curvularia lunata, Epicoccum nigrum, Fonsecaea pedrosei, Microsporum eqiunum, Mucor sp., Rhizopus sp., Savoryella paucispora, and Trichoderma sp. Out of these, five species were found in both locations: Acremonium sp., Epicoccum nigrum, Fonsecaea pedrosei, Microsporum eqiunum, and Rhizopus sp. More marine fungi were recorded from the mangroves of Tok Bali, Kelantan. Final identification revealed a total of 25 species of fungi with seven species classified as aquatic fungi of which six were marine fungi: Koralionastes augustus, $K$. violaceus, Haloguignardia cystoseirae, Pontogeneia calospora, Trematosphaeria mangrovei and Savoryella paucispora, and one freshwater fungus, Trichoderma sp. (Table 2).

Fewer aquatic fungi were obtained and this could be due to the salinity factor. The samples were taken after a rainfall which had resulted in the flushing of freshwater and sediment to the mangrove habitat that led to lower salinity. Under low salinity, fresh water and terrestrial fungi were involved in litter conditioning while the activities of marine fungi were only supported when the salinity increased (Barnett \& Hunter, 1998).

\section{Screening for cadmium-tolerant aquatic fungi}

The screening for Cadmium-tolerant aquatic fungi showed that Trichoderma sp. was the most tolerant fungus to $\mathrm{Cd}$ among the seven aquatic fungi tested (Table 3). This was followed by P. calospora, S. paucispora, K. augustus, $H$. cystoseirae, $T$. mangrovei and $K$. violaceus, indicating that the fungus is a good biosorption agent. Trichoderma genus comprises a great number of fungal strains that act as biological control agents and the antagonistic properties are based on the activation of multiple mechanisms (Benitez et al., 2004).

The success of Trichoderma strains as biocontrol agents is due to their high reproductive capacity, ability to survive under very unfavorable conditions, efficiency in the utilization of nutrients, capacity to modify the rhizosphere, strong aggressiveness against phytopathogenic fungi, and efficiency in promoting plant growth and defense mechanisms. These properties have made 
Table 1. Morphological descriptions of terrestrial fungi isolated from Avicennia alba, Rhizophora apiculata and Sonneratia caseolaris in UMT and Tok Bali, Kelantan

\begin{tabular}{|c|c|c|c|c|}
\hline \multirow{2}{*}{ Species } & \multicolumn{3}{|c|}{ Morphology } & \multirow{2}{*}{ Location/Origin } \\
\hline & $\begin{array}{l}\text { Colour of } \\
\text { hyphae }\end{array}$ & $\begin{array}{l}\text { Appearance of } \\
\text { spores }\end{array}$ & $\begin{array}{l}\text { Texture of } \\
\text { cultures }\end{array}$ & \\
\hline Absidia corymbifera & Grey & White & Fleshy & UMT \\
\hline Acremonium sp. & White & White & Downy & UMT \& Tok Bali \\
\hline Apophysomyces elegans & White Cream & White & Fleshy & Tok Bali \\
\hline Aspergillus sp. & White & Dark Green & Cottony & Tok Bali \\
\hline Aureobasidium pulullans & Brown & Dark Brown & Mouldy & Tok Bali \\
\hline Chaetomium globosum & White & White Cream & Downy & Tok Bali \\
\hline Chrysosporium sp. & White & Dark Green and White & Cottony & UMT \\
\hline Cladosporium herbarum & Dark Green & Dark Green & Downy & Tok Bali \\
\hline Curvularia lunata & Black & Black & Downy & UMT \\
\hline Epicoccum nigrum & Brown & Dark Brown & Mouldy & UMT \& Tok Bali \\
\hline Fonsecaea pedrosei & Black & Black & Mouldy & UMT \& Tok Bali \\
\hline Microsporum eqiunum & Bright Yellow & Cream & Slimy & UMT \& Tok Bali \\
\hline Microsporum sp. & Yellow Cream & Light Green & Downy & Tok Bali \\
\hline Mucor sp. & Dark Grey & Dark Grey & Downy & UMT \\
\hline Phialophora sp. & Dark Red & Dark Red & Downy & Tok Bali \\
\hline Trichophyton sp. & Cream & White & Mouldy & Tok Bali \\
\hline Trichophyton violaceum & Deep Violet & Deep Violet & Mouldy & Tok Bali \\
\hline Rhizopus sp. & Greenish Grey & Light Green & Cottony & UMT \& Tok Bali \\
\hline Koralionastes augustus & Cream & Light Brown & Slimy & Tok Bali \\
\hline Koralionastes violaceus & White Cream & Light Brown & Slimy & Tok Bali \\
\hline Haloguignardia cystoseirae & Brownish Cream & Dark Brown & Slimy & Tok Bali \\
\hline Pontogeneia calospora & Brown & Black & Mouldy & Tok Bali \\
\hline Trematosphaeria mangrovei & Bright Yellow & Cream & Slimy & Tok Bali \\
\hline Savoryella paucispora & Brown & Light Brown & Cottony & UMT \\
\hline Trichoderma sp. & Light Green & Greenish White & Cottony & UMT \\
\hline
\end{tabular}

Table 2. Morphological descriptions of hyphae and microscopic view of fungal cultures isolated from Avicennia alba, Rhizophora apiculata and Sonneratia caseolaris in UMT and Tok Bali, Kelantan

\begin{tabular}{|c|c|c|c|c|c|c|c|}
\hline & & & & Fungi & & & \\
\hline & $\begin{array}{c}\text { Koralionastes } \\
\text { augustus }\end{array}$ & $\begin{array}{c}\text { Koralionastes } \\
\text { violaceus }\end{array}$ & $\begin{array}{c}\text { Haloguignardia } \\
\text { cystoseirae }\end{array}$ & $\begin{array}{l}\text { Pontogeneia } \\
\text { calospora }\end{array}$ & $\begin{array}{c}\text { Trematosphaeria } \\
\text { mangrovei }\end{array}$ & $\begin{array}{l}\text { Savoryella } \\
\text { paucispora }\end{array}$ & Trichoderma sp. \\
\hline \multicolumn{8}{|l|}{ Top } \\
\hline \multicolumn{8}{|l|}{ Bottom } \\
\hline \multicolumn{8}{|l|}{$\begin{array}{c}\text { Microscopic } \\
\text { (Magnification) }\end{array}$} \\
\hline & $40 x$ & $40 x$ & $100 x$ & $100 x$ & $40 x$ & $40 x$ & $40 x$ \\
\hline Colour of hyphae & Cream & White Cream & Brownish Cream & Brown & Bright Yellow & Brown & Light Green \\
\hline
\end{tabular}


Table 3. Growth of mangrove aquatic fungi in different cadmium concentrations

\begin{tabular}{lcccccccccccc}
\hline \multirow{2}{*}{ Fungi } & \multicolumn{10}{c}{ Concentration of $\mathrm{CdCl}_{2}(\mu \mathrm{M})$} \\
\cline { 2 - 12 } & 0 & 0.05 & 0.10 & 0.15 & 0.20 & 0.25 & 0.30 & 0.35 & 0.40 & 0.45 & 0.50 \\
\hline Trichoderma sp. & +++ & +++ & +++ & +++ & +++ & ++ & ++ & ++ & ++ & + & + \\
Trematosphaeria mangrovei & +++ & ++ & ++ & ++ & ++ & + & + & + & + & - & - \\
Savoryella paucispora & +++ & ++ & ++ & ++ & ++ & + & + & - & - & - & - \\
Koralionastes violaceus & +++ & ++ & ++ & ++ & ++ & + & - & - & - & - & - \\
Koralionastes augustus & +++ & ++ & ++ & ++ & ++ & + & - & - & - & - & - \\
Haloguignardia cystoseirae & +++ & ++ & ++ & + & + & - & - & - & - & - & - \\
Pontogeneia calospora & +++ & ++ & + & - & - & - & - & - & - & - & - \\
\hline
\end{tabular}

+ = weak growth; ++ = moderate growth; +++ = good growth; - = no growth.

Trichoderma a ubiquitous genus present in any habitat and at high population densities (Chet et al., 1997). Benitez et al. (2004) have described the biocontrol mechanisms of various Trichoderma strains such as $T$. harzianum, $T$. virens and $T$. hamatum in different aspects especially as a biofertilizer and plant protector.

\section{Molecular identification of the heavy metal tolerant fungus}

The BLAST search further confirmed the identity of Trichoderma sp. as Trichoderma atroviride, where the sequence data of the isolated fungi shared $98 \%$ homology with the $28 \mathrm{~S}$ ribosomal RNA gene of Trichoderma atroviride (EF591763). The gene was also highly identical to Hypocrea rufa but the morphological characteristics are slightly different compared to selected fungi screened previously. H. rufa was different in color and shape of spores but only $T$. atroviride matched both morphologically and genetically. Previously, T. atroviride was widely studied as an antifungal agent by the production of chitinase during mycoparasitism (Mach et al., 1999; Benitez et al., 2004) but no report on the studies of heavy metal detoxification in T. atroviride is available.

\section{Higher tolerance to cadmium study}

Trichoderma atroviride was found to be highly tolerant to $\mathrm{Cd}$ where growth was possible in up to $3.0 \mathrm{mM} \mathrm{CdCl}$, although the diameter of the mycelial growth decreased with increased concentration of $\mathrm{Cd}$, indicating weaker growth (Table 4). In the absence of $\mathrm{Cd}$, growth of mycelia increased remarkably on day 2 of incubation and achieved almost full-blown growth on day 5. In the presence of $\mathrm{Cd}$, the highest concentration of $\mathrm{Cd}$ in PDA that T. atroviride could tolerate to achieve full growth on day 14 was $0.75 \mathrm{mM} \mathrm{CdCl}_{2}$. With the highest $\mathrm{Cd}$ in media $(3.0 \mathrm{mM})$, the fungal growth was reduced to $58.5 \%$ on day 14 .
According to Baldrian (2003), the hyphae aerial of fungus Schizophyllum commune in solid media containing Cd was increased and the growth segment was changed. Loops and connective filaments were developed together with an increase of hyphal branching and the extent of these changes reflected the increasing concentration of the metal ion. Additionally, the sporulation by $T$. atroviride growing in $\mathrm{Cd}$ was also affected, despite the tolerance to $\mathrm{Cd}$. The control fungus started to sporulate around day 5 involving younger culture at the edge of the plate. As for the Cd-treated fungus, the culture remained whitish, indicating a lack of sporulation, as supported by the microscopic view which shows that the formation of spore decreased when the concentration of $\mathrm{Cd}$ was increased.

\section{CONCLUSION}

From the two mangroves areas in the east coast of Peninsular Malaysia - Tok Bali and UMT - a total of 25 species of fungi was isolated but only seven aquatic fungi were found. The only freshwater fungus isolated, Trichoderma atroviride, was found to be the most tolerant to the heavy metal cadmium, to up to $3.0 \mathrm{mM}$. The ability of this fungus to withstand high toxicity of cadmium provides a potential source of new bioremediation agent that could bring benefits to the waste-water treatment industry. It is recommended that studies be carried out in the future on the cadmium detoxification mechanism in $T$. atroviride, to provide greater insights on the roles of bioactive compounds and metabolites during the process. This would also lead to the identification of potential biomarkers to detect cadmium contamination in the environment. 
Table 4. Effect of cadmium concentration on the growth of $T$. atroviride on PDA at $30^{\circ} \mathrm{C}$

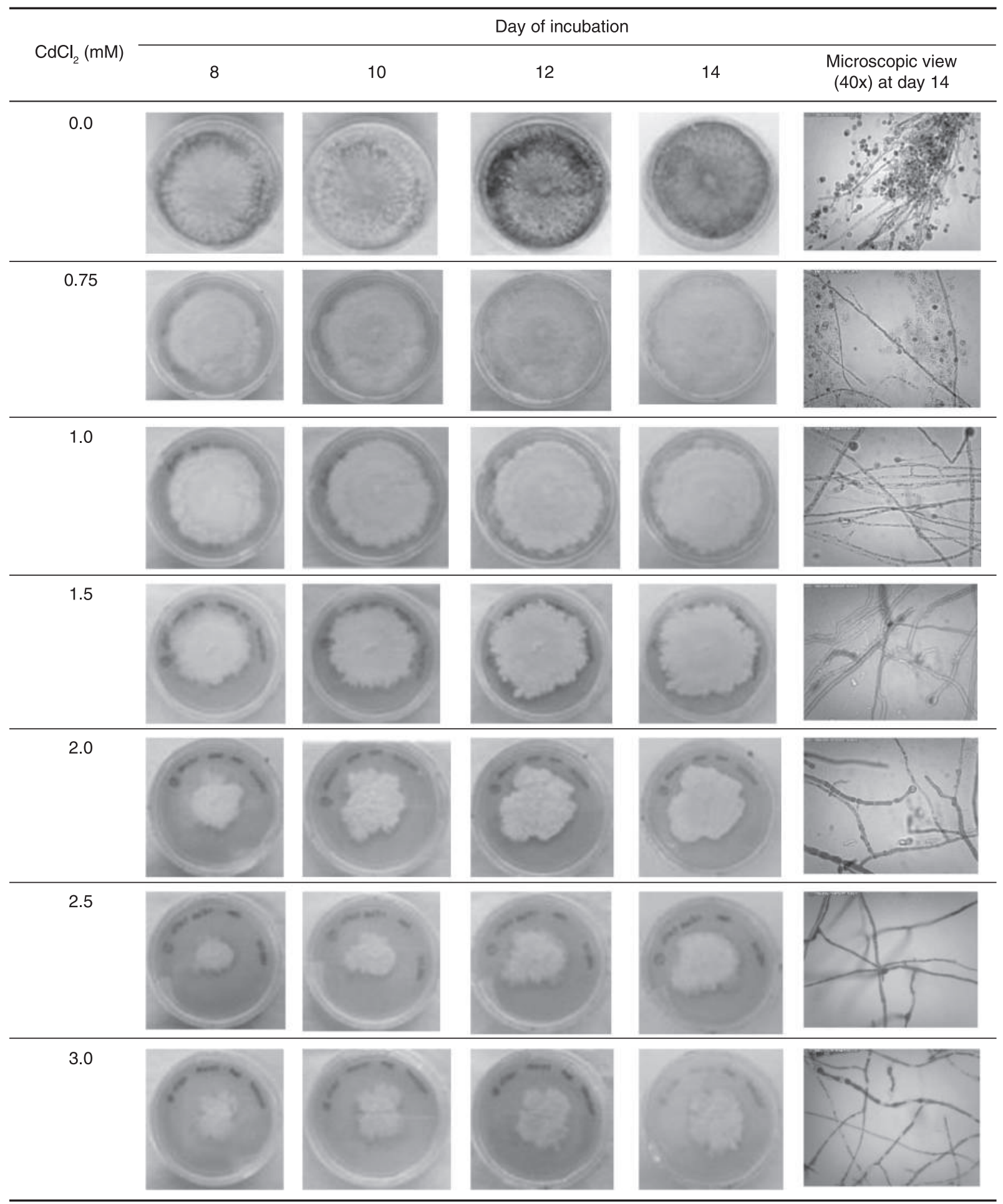

\section{ACKNOWLEDGEMENTS}

The authors would like to acknowledge the assistance given by the Ministry of Education Malaysia with the financial support under the Fundamental Research Grant Scheme (FRGS/2/
2013/ST04/UMT/02/1) and to the Institute of Marine Biotechnology, Faculty of Science and Marine Environment, Central Lab of UMT and the Institute of Systems Biology, Universiti Kebangsaan Malaysia for technical support. 


\section{REFERENCES}

Anand, P., Isar, J., Saran, S. \& Saxena, R.K. 2006. Bioaccumulation of copper by Trichoderma viride. Bioresource Technology, 97(8): 10181025.

Baldrian, P. 2003. Interactions of heavy metals with white-rot fungi. Enzyme and Microbial Technology, 32(1): 78-91.

Barnett, H.L. \& Hunter, B.B. 1998. Illustrated Genera of Imperfectii Fungi. 4th Ed. APS Press, USA.

Benitez, T., Rincon, A.M., Limon, M.C. \& Codon, A.C. 2004. Biocontrol mechanisms of Trichoderma strains. International Microbiology, 7(4): 249-260.

Chen, S.H., Ng, S.L., Cheow, Y.L. \& Ting, A.S.Y. 2017. A novel study based on adaptive metal tolerance behaviour in fungi and SEM-EDX analysis. Journal of Hazardous Materials, 334: 132-141.

Chet, I., Inbar, J. \& Hadar, I. 1997. Fungal antagonists and mycoparasites. In: The Mycota $I V$ : Environmental and Microbial Relationships. D.T. Wicklow and B. Soderstrom (Eds.). Springer-Verlag, Berlin. pp. 165-184.

Coughtrey, P.J. \& Martin, M.H. 1977. Cadmium tolerance of Holcus lanatus from a site contaminated by aerial fallout. New Phytologist, 79: 273-280.

Deacon, J.W. 1997. Modern Mycology (3rd Ed.). Blackwell Science, London.

Dighton, J., White, J.F. \& Oudemans, P. 2005. The Fungal Community: Its Organization and Role in The Ecosystem. 3rd Ed. CRC Press, Boca Raton.

Dix, N.J. \& Webster, J. 1995. Fungal Ecology. Chapman and Hall, London.

Ellis, D., David, S., Alexiou, H., Pfeiffer, T. \& Manatakis, Z. 1992. Descriptions of Medical QAP Fungi. Mycology Unit, North Adelaide.

Friberg, L. \& Vahter, M. 1983. Assessment of exposure to lead and cadmium through biological monitoring: results of a UNEP/WHO global study. Environmental Research, 30(1): 95-128.

Gupta, R. 2004. A Textbook of Fungi. A Plt Publishing Corporation, New Delhi.

International Cadmium Association (ICdA). 2009. [WWW Document]. URL http://www.cadmium. org/ (accessed 03.08.20).

Jaeckel, P., Krauss, G., Menge, S., Schierhorn, A., Rucknagel, P. \& Krauss G.J. 2005. Cadmium induces a novel metallothionein and phytochelatin 2 in an aquatic fungus. Biochemical and Biophysical Research Communications, 333: 150-155.
Jaishankar, M., Tseten, T., Anbalagan, N., Mathew, B.B. \& Beeregowda, K.N. 2014. Toxicity, mechanism and health effects of some heavy metals. Interdisciplinary Toxicology, 7(2): 6072.

Järup, L. 2003. Hazards of heavy metal contamination. British Medical Bulletin, 68: 167182.

Jones, E.B.G. \& Alias, S.A. 1997. Biodiversity of mangrove fungi. In: Biodiversity of Tropical Microfungi. K.D. Hyde (Ed.). Hong Kong University Press, Hong Kong. pp. 71-92.

Jones, E.B.G. \& Hyde, K.D. 1988. Methods for the study of mangrove marine fungi. In: Mangrove Microbiology: Role of Microorganisms in Nutrient Cycling of Mangrove Soils and Waters. A.D. Agate, C.V. Subramaniam and M. Vannucci (Eds.). UNDP/UNESCO. pp. 9-27.

Heiss, S., Wachter, A., Bogs, J., Cobbett, C. \& Rausch, T. 2003. Phytochelatin synthase (PCS) protein is induced in Brassica juncea leaves after prolonged $\mathrm{Cd}$ exposure. Journal of Experimental Botany, 54(389): 1833-1839.

Kneer, R., Kutchan, T.M., Hochberg, A. \& Zenk, M.H. 1992. Saccharomyces cerevisiae and Neurospora crassa contain metal sequestering phytochelatins. Archives of Microbiology, 157: 305-310.

Kohlmeyer, J. \& Kohlmeyer, E. 1979. Marine Mycology: The Higher Fungi. Academic Press, New York.

Luo, W., Vrijmoed, L.L.P. \& Jones, E.B.G. 2005. Screening of marine fungi for lignocellulosedegrading enzyme activities. Botanica Marina, 48(5-6): 379-386.

Mach, R.L., Peterbauer, C.K., Payer, K., Jaksits, S., Woo, S.L., Zeilinger, S., Kullnig, C.M., Lorito, M. \& Kubicek, C.P. 1999. Expression of two major chitinase genes of Trichoderma atroviride (T. harzianum P1) is triggered by different regulatory signals. Applied Environmental Microbiology, 65: 1858-1863.

Min, B., Choi, S.Y. \& Lee, S.Y. 1997. Effect the cadmium treatment on the total thiol groups, glutathione and phytochelatin contents in Oenanthe javanica. Agriculture and Chemistry Biotechnology, 40(3): 242-248.

Morais, S., Costa, F.G.E. \& Pereira, M. de L. 2012. Heavy metals and human health - emerging issues and practice. InTech, 227-246.

Murasugi, A., Wada, C. \& Hayashi, Y. 1981. Purification and unique properties in UV and CD spectra of Cd-binding peptides 1 from Schizosaccromyces pombe. Biochemical and Biophysical Research Communications, 103: 1021-1028. 
Riddell, R. 1950. Permanent stained mycological preparations obtained by slide culture. Mycologia, 42(2): 265-270.

Sadiq, M. 1992. Toxic Metal Chemistry in Marine Environments. CRC Press, USA.

Sarma, V.V. \& Hyde, K.D. 1999. A synoptic key to higher marine fungi. In: Techniques for Studying Marine Fungi. K.D. Hyde, S. Pointing and T.K. Tan (Eds.). Fungal Diversity Press Research Series 1, Hong Kong.
Silver, S. \& Phung, L.T. 1996. Bacterial heavy metal resistance: new surprises. Annual Review of Microbiology, 50: 753-789.

Simon, E. 1977. Cadmium tolerance in populations of Agrostis tenuis and Festuca ovina. Nature, 265: 328-330.

Simonescu, C.M. \& Ferdeş, M. 2012. Fungal biomass for $\mathrm{Cu}$ (II) uptake from aqueous systems. Polish Journal of Environmental Studies, 21(6): 18311839. 